\title{
Новая концепция пировидикона на основе пироэлектрического электронно-оптического преобразователя диапазона 1-12 мкм
}

\author{
О.Е. Терещенко ${ }^{1,2}$, С.В. Иванов ${ }^{3}$, Н.А. Половников ${ }^{1}$, А.А. Соколов ${ }^{3}$, В.С. Русецкий ${ }^{1,4}$, \\ В.А. Голяшов ${ }^{1,2}$, А.С. Ярошевич ${ }^{1}$, А.В. Миронов ${ }^{4}$, А.Ю. Дёмин ${ }^{4}$ \\ ${ }^{1}$ Институт физики полупроводников им. А.В. Ржсанова СО РАН, 630090, Новосибирск, Россия \\ teresh@isp.ncs.ru \\ ${ }^{2}$ Новосибирский государственный университет, 630090, ул. Пирогова, 2, Новосибирск, Россия \\ ${ }^{3}$ Институт автоматики и электрометрии СО РАН, 630090, Новосибирск, Россия \\ ${ }^{4} 3 А О$ «ЭКРАН-ФЭП», ул. Зеленая горка, д.1, Новосибирск, Россия \\ тел:+7 (383) 330-7883, эл. почта: teresh@isp.nsc.ru
}

DOI $10.34077 /$ RCSP2021-33

Неохлаждаемые пироэлектрические преобразователи теплового изображения (пириконы) в среднем и дальнем инфракрасном (ИК) диапазонах спектра, обладают свойством неселективности по спектру и детектируют только изменение интенсивности падающего излучения. Благодаря этим свойствам они находят широкое применение в ИК-технике для точных спектральных измерений, наблюдения и распознавания объектов, медицинской и промышленной диагностике, а также для специальных применений.

Основная цель работы - реализация концепции создания неохлаждаемых тепловизионных приборов с высоким пространственным разрешением, формирующих тепловое изображение в диапазоне длин волн 1-14 мкм, на основе пироэлектрических пленок $\mathrm{Sr}_{1-\mathrm{x}} \mathrm{Ba}_{\mathrm{x}} \mathrm{Nb}_{2} \mathrm{O}_{6}(\mathrm{SBN}) \mathrm{c}$ использованием внутреннего усиления.

В работе представлена концепция пировидикона, представляющих собой пирикон со сплошной мишенью из пироэлектрика $\mathrm{Sr}_{1-\mathrm{x}} \mathrm{Ba}_{\mathrm{x}} \mathrm{Nb}_{2} \mathrm{O}_{6}$, интегрированной в вакуумный фотодиод $\mathrm{c}$ мультищелочным фотокатодом. В отличие от стандартного пировидикона роль катода выполняет мультищелочной катод, а сканирование электронным пучком осуществляется разверткой лазерного луча. Изменение температуры, вызванное инфракрасным изображением, создает соответствующее распределение потенциала, которое считывается сканирующим электронным лучом. К преимуществу пирикона можно отнести отсутствие мультиплексора, роль которого выполняет считывающий электронный пучок. Недостатком - отсутствие внутреннего усиления пироэлектрического сигнала. Одним из решений преодоления отмеченного недостатка является создание пироэлектрического электронно - оптического преобразователя (ПЭОП) [1].

Нами предложен ПЭОП с пиромишенью на основе пленки SBN со сквозными отверстиями для прохождения электронного потока, который модулируется в соответствии с распределением потенциала на поверхности мишени, возникающим при проецировании на мишень теплового излучения. В работе изучены пироэлектрические и оптические свойства пленок SBN:La толщиной 0.52.5 мкм, выращенные методом высокочастотного вакуумного осаждения на поверхность тонких металлических фольг и кремния. Изучен состав, структура и морфология полученных пленок SBN. Полученные величины пирокоэффициента $\gamma$ варьировались в диапазоне $6.1-81.5$ нКл/(см ${ }^{2}$ К) в зависимости от температуры роста и толщины пленок. Изучен фазовый переход.

Собран первый прототип ПЭОП на основе ЭОП-2+, в котором изучены фотоэмиссионные свойства и проведены измерения энергетического распределения фотоэлектронов, проходящих сквозь пиромишень.

\section{Лumepamypa}

[1] С.М. Зорин, Б.Г. Гончаренко, В.В. Козлов, А.Н. Романов, В.Д. Салов, Известия высших учебных заведений. Материалы электронной техники. 18, 205 (2015). 